
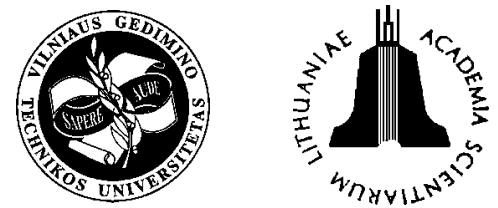

JOURNAL OF CIVIL ENGINEERING AND MANAGEMENT

http:/www.vtu.lt/english/editions

2004, Vol X, No 1, 51-60

\title{
ANALYSIS OF EXPERIENCE AND EFFICIENCY OF DISTANCE LEARNING MASTER'S DEGREE PROGRAMME IN CONSTRUCTION ECONOMICS AND PROPERTY MANAGEMENT
}

\author{
Silva Rimkuviené ${ }^{1}$, Natalija Lepkova ${ }^{2}$ \\ Dept of Construction Economics and Property Management, Vilnius Gediminas Technical University, \\ Sauletekio al. 11, LT-10223 Vilnius-40, Lithuania.E-mail: ${ }^{1}$ Silva.Rimkuviene@st.vtu.lt; \\ 2 Natalija.Lepkova@st.vtu.lt
}

Received 17 Nov 2003; accepted 19 Feb 2004

\begin{abstract}
This paper reviews the distance learning development in the world and in Lithuania. Nine years of theoretical and practical experience of distance learning under two study programmes at the Department of Construction Economics and Property Management at Vilnius Gediminas Technical University is presented. These masters degree study programmes were one of the first in Central and Easten Europe. According to the questionnaire of both former and current students, the findings of this poll are analysed. Mostly there were employees from real estate sector and construction enterprises questioned. The conclusions are drawn, emphasising the problems of learning process. In addition, social, economical, technological, and ethical points are analysed as well as the problem of the integration of trained professionals into the market.
\end{abstract}

Keywords: distance learning, electronic textbooks, video and computer software, computer learning systems, computer conferencing.

\section{Introduction}

Distance learning has evolved over the past two centuries from correspondence courses to educational radio, one- and two-way teleconferencing, educational television, video conferencing to computer assisted/Webbased interactive learning opportunities. Yet, with all the technological changes that have evolved in distance learning, there have been few changes in the reason why distance learning exists. Distance learning is intended to offer useful learning opportunities to people at a time and location convenient to them [1].

Distance learning is a process of teaching-learning in which the learner is physically separated from the teacher. The geographical distances involved may be relatively small or very large. Most definitions accept that there may be a degree of physical interaction between teacher and learner, but in comparison with the normal classroom experience the actual amount of faceto-face contact is usually much reduced or even nonexistent. Because of this, the teacher develops a range of learning materials to impact knowledge, skills and attitudes to the learner. The presence of such technical media (print, audio, video, computer-based) is a distinguishing feature of distance education. Students study these materials, generally alone, at times and in places of their own choosing. There are arrangements to test their knowledge, skills and attitudes through assignments that are sent to a tutor for marking, or marked by computer [2].
In the period from 1991 to 2003 new technologies were developing at an enormous rate. As a result of introduction of such new modern technologies, distance learning has also undergone some rapid improvements, various distance learning media (web ct, learning space, etc) have come into existence, computing capabilities have risen up thousandfold and students are now given an unprecedented opportunity of completing their studies without travelling to their universities [3].

In 1993 Lithuania joined the Phare Multi-country Programme for Distance Education. In 1994 the Lithuanian Centre for Distance Learning was established by the order of the Minister of Education and Science; this centre was charged with the implementation of this programme in Lithuania. The development of distance learning network is supported through public funding. In 1998 the Development of Distance Learning in Lithuania programme was undertaken as part of the Government Investment Project [3].

In 1998 the Lithuanian distance learning network LieDM was established [4].

\section{Development of idea and distance learning courses at the Faculty of Civil Engineering of VGTU}

The idea to create distance learning programmes at the Faculty of Civil Engineering of VGTU originated in 1993-1995 while working on the international PHARE 
project between VGTU and the Department of Surveying of Salford University. This department is considered one of the front-runners among 60 other similar departments in Great Britain. While implementing the project Prof A. Kaklauskas, with the help of Prof B. Sloan, familiarised himself with computer learning systems, methods for their creation and the principles of distance learning programmes.

As a result of the above-mentioned project came up the idea to present this new and modern form of learning at the VGTU. Two international projects were initiated:

1. "Computer learning systems" under TEMPUS programme;

2. "Creation of distance learning Master degree programmes" (jointly between the VGTU and Napier University in Great Britain) under PHARE programme.

The project under Tempus programme was successfully implemented in 1996-1997. Prof A. Kaklauskas worked at Napier University (Great Britain) in which distance learning programmes are advanced. He worked together with the head of distance learning studies Prof B. Sloan [5] and gained extensive experience relating to distance learning programmes and computer learning systems.

The project proposal did not obtain financing under PHARE programme, therefore it was decided to create distance learning programmes by ourselves, using the resources of VGTU. Professors A. Kaklauskas and E. K. Zavadskas took the initiative of implementing this project. The first distance learning courses were created without any financial support, only thanks to the efforts of Professors E. K. Zavadskas, R. Ginevičius, A. Kaklauskas, P. Vainiūnas, A. V. Rutkauskas, G. Marčiukaitis and Assoc Prof S. Raslanas. M. Gikys started preparing multimedia materials.

The first distance learning programme at the Dept of Construction Economics and Property Management of the Faculty of Civil Engineering of VGTU was introduced in September of 1999. It was one of the first Master degree programme in Central and Eastern Europe. 27 students from all over Lithuania were accepted onto the Real Estate Valuation programme. Most of them were people working in the real estate sector. Over the period of four years this study programme has been renamed once (in 2001 its name was changed to "Real Estate Valuation and Management") and its content and scope have also been subjected to changes. Since 2003, the Real Estate Valuation and Management programme contains two major subjects: Real Estate Management and Internet Technologies and Real Estate Business. Since 2000, students can enrol in Construction Management distance learning course selecting Construction Economics and Management as a major subject [6].

All programme materials are available as printed programme notes which are enhanced, where appropriate, to take advantage of modern teaching techniques and delivery mechanisms. In particular, the following media are used in specific modules: electronic format of the textbooks, video, computer software, computer learning systems, computer conferencing, computer networks, 'face-to-face' contact. The choice of media is often relatively easy to make because for much of the time, local constraints, questions of accessibility and of cost virtually dictate the media through which learners will have to work. Accessibility is vitally important to any learners who have to use self-instructional materials.

The module writers utilised electronic technologies in the preparation of their module material. This assisted the programmeming team to prepare the material in a variety of suitable formats for dissemination. Once in electronic format the material can be made available in paper format, on $\mathrm{CD}$, over the Internet and by file transfer (FTP). This ensures that the learners can have the material available in the way which best suits their learning needs. Equipment, such as video-recorders and computers, are utilised wherever possible. In addition, faceto-face contact, telephone, fax, surface mail, e-mail are also used.

Study materials are prepared with reference to Great Britain, Germany, the USA and other countries' experience [7].

The present paper analyses in more detail the composition of the student body by emphasising the problems of the learning process, the social, economic, moral issues related to the labour market integration of trained professionals, etc.

At the present time the distance learning division of the Dept of Construction Economics and Property Management has 181 graduate students from Lithuania and 4 citizens of Lebanon who use the English version of learning materials.

The following tables and figures (Fig 1) illustrate the variation in the number of students from the first year to the present.

Judging by data presented in Table 1 and 2, the number of students who entered and successfully completed distance learning programmes ranges from 0 to 31. However, the number of students who dropped out is not consistent: for instance, there were no dropouts in the group which graduated in 2001 . We provide evidence that for the most part the reasons for student dropout are social and economic (students fail to combine work with studies, go abroad, are not able to pay the tuition fee, etc). It also should be noted that most of those who selected Construction Economics and Business as their major subject are men whereas the numbers of men and women in Real Estate Valuation and Management programme are roughly equal.

\section{Analysis of questionnaire-based survey results}

In order to clarify a number of issues related to the study process (first and foremost the student motivation, efficiency of advertising, issues related to the quality of 
Table 1. Variation in the number of students in the „Real Estate Valuation and Management“ (RPVM) programme

\begin{tabular}{c|c|c|c|c|c|c}
\hline \multirow{2}{*}{ Academic year } & \multicolumn{3}{|c|}{ Students from all years } & \multicolumn{3}{c}{ Senior students in their last year of study } \\
\cline { 2 - 7 } & Men & Women & Total & Men & Women & Total \\
\hline $1999-2000$ & 15 & 12 & 27 & 0 & 0 & 0 \\
\hline $2000-2001$ & 46 & 30 & 76 & 15 & 12 & 27 \\
\hline $2001-2002$ & 30 & 30 & 60 & 15 & 14 & 29 \\
\hline $2002-2003$ & 29 & 50 & 79 & 8 & 14 & 22 \\
\hline $2003-2004$ & 50 & 55 & 105 & 22 & 34 & 56 \\
\hline
\end{tabular}

Table 2. Variation in the number of students in the Construction Management programme who have selected Construction Economics and Business (CEB) as a major subject

\begin{tabular}{c|c|c|c|c|c|c}
\hline \multirow{2}{*}{ Academic year } & \multicolumn{3}{|c|}{ Students from all years } & \multicolumn{3}{c}{ Senior students in their last year of study } \\
\cline { 2 - 7 } & Men & Women & Total & Men & Women & Total \\
\hline $2000-2001$ & 19 & 9 & 28 & 0 & 0 & 0 \\
\hline $2001-2002$ & 23 & 18 & 41 & 9 & 8 & 17 \\
\hline $2002-2003$ & 44 & 19 & 63 & 7 & 9 & 38 \\
\hline $2003-2004$ & 49 & 27 & 76 & 29 & 9 & 16 \\
\hline
\end{tabular}

\subsection{Analysis of information about respondents}

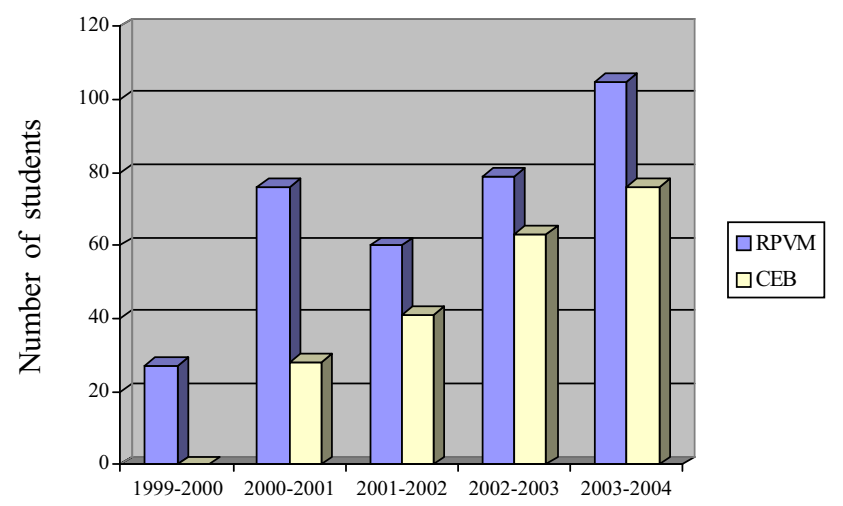

Academic year

Fig 1. Variation in the number of students in distance learning programmes

study materials, reaction of social environment, etc) a survey research was conducted.

Since it is impossible to cover the body of students from all five years, we selected 125 respondents from those who have already completed their distance study programmes (16 respondents) and those who are still studying (109 respondents). The respondents were asked to answer the questionnaire which contained the following three main parts (see Appendix):

1. Information about the respondent;

2. Information about the studies;

3. Analysis of the study materials;

4. Social aspects of studies.

The following is an analysis of the data obtained through questionnaire-based survey.
A successful distance learning programmes must not only utilize cutting-edge technology, it must also encourage the development of innovative methods to address the needs of special populations [8].

First of all we conducted the analysis of the information about the respondents (age, place of residence, occupation).

In total, 125 respondents took part in the survey (65 men and 60 women) (Fig 2).
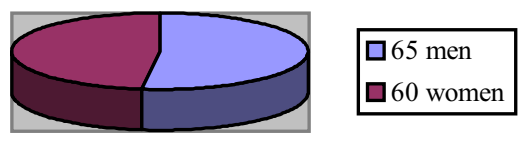

Fig 2. Distribution of respondents by sex

The age of respondents ranged from 21 to 56 years.

As can be seen from Fig 3, even though students enrolled on distance learning course are people belonging to different age groups, the majority of them (51 respondent $-45 \%$ ) are young men and women under

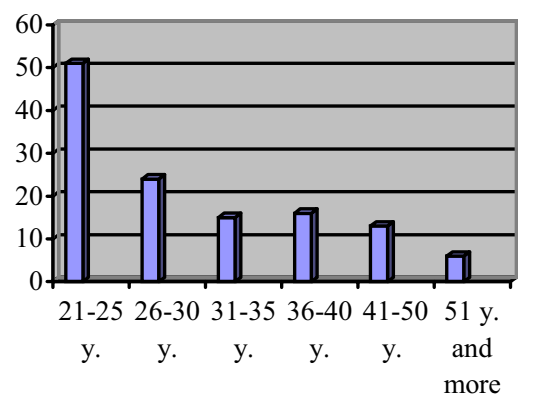

Fig 3. Distribution of respondents by age groups 
the age of 25. Sometimes people 37 years of age and over also decide to enrol in a study programme and they account for $25 \%$ of respondents. This is most welcome news.

Distribution of those polled by the place of residence is shown in Fig 4.

As can be seen in Fig 4, most students come from Vilnius. We provide evidence that this is due to economic and social reasons and high concentration of workplaces in the city of Vilnius.

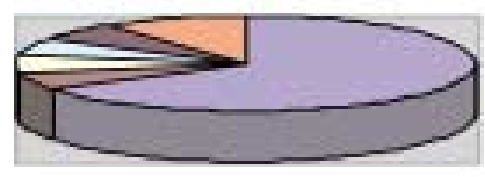

\begin{tabular}{|c|}
\hline 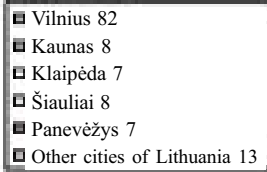 \\
\hline
\end{tabular}

Fig 4. Distribution of respondents by place of residence

The distribution of respondents by type of employment is shown in Fig 5.

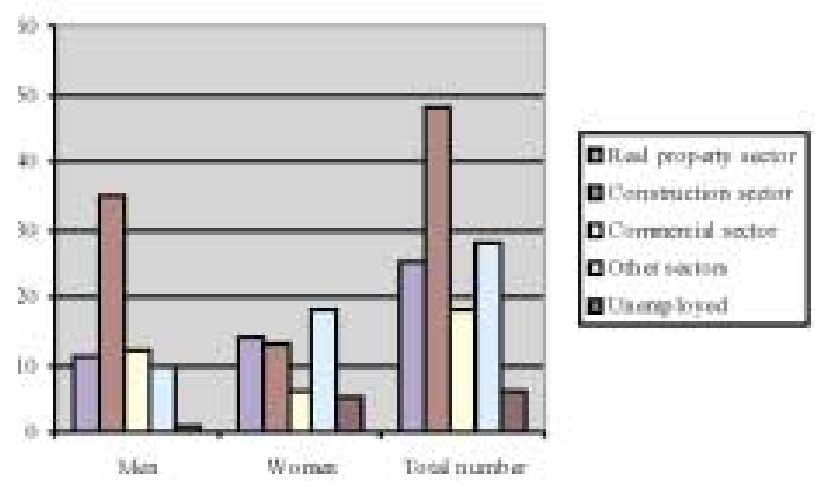

Fig 5. Distribution of respondents by type of employment

As can be seen in Fig 5, the overwhelming majority of respondents are employed. Only 6 of them (mostly women looking after their small children) are temporarily out of work. The greatest number of respondents (especially men) work in the construction sector. One fifth of those polled work in the real estate sector.

\subsection{Analysis of information about the studies}

The following is the further analysis of the results obtained from part 2 of the questionnaire (information about the studies).

Student motivation and the purpose of studies form a very important part of the questionnaire. When answering these questions the respondents were permitted to indicate all motives which they considered important (Fig 6).

The overwhelming majority of those polled indicated that the most important advantage of distance studies is the opportunity to study and continue working at the same time, since this was the only way to pursue studies. About half of respondents said they wanted to acquire an additional profession, improve their skills and get a better job in the future.

Majority of those polled indicated that their decision to choose this form of studies was determined mostly by the desire to get acquainted with the modern information technologies, save time, get regular access to most up-to-date information and fast communication. There are also other important reasons: flexible choice of academic subjects, good teachers and good level of professional training.

Distance learning is attractive to the respondents also because it is a new and progressive form of studies.

All respondents agreed that Saturday is the best day to hold contact meetings. They wanted to continue corresponding with their teachers and tutors by email and contact them by phone. Some of them wanted to communicate via video conferences. Also, all respondents indicated that for them a 4 semester course with the existing tuition fee would be most appropriate.

The reliability and efficiency of information about distance studies is an important research object.

It should be noted that in their answers to this question the respondents were allowed to specify several options and give them points.

As can be seen from this analysis, the Internet is considered the most efficient source of information. It was indicated by as many as $43 \%$ (54 respondents) of
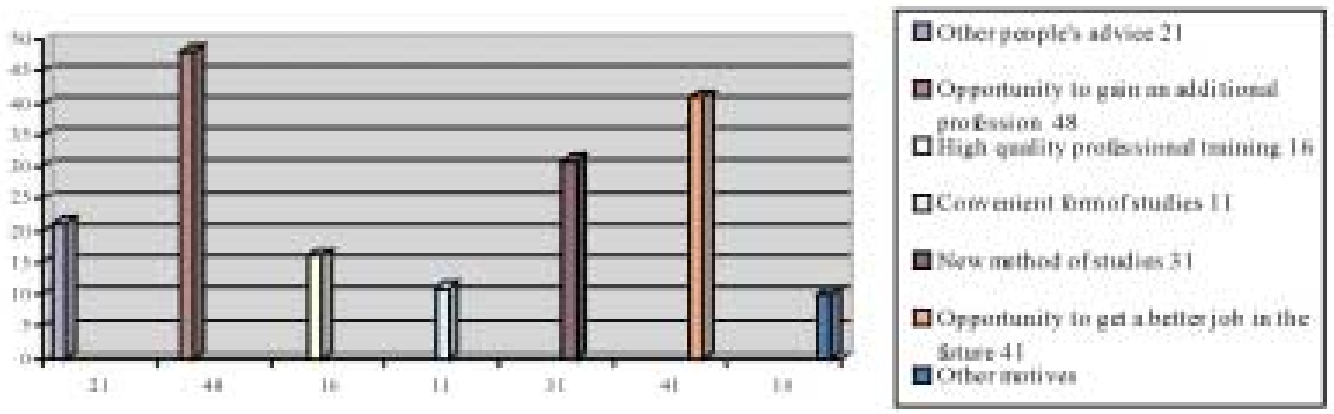

Fig 6. Distribution of respondents by motives of studies 


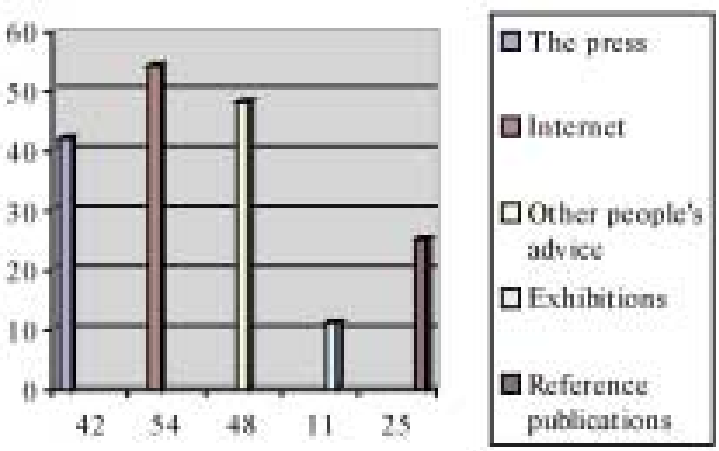

Fig 7. Respondents' opinions about the reliability of sources of information

those polled. The second most popular source is other people's advice, the third - information published in newspapers, etc (Fig 7).

As is well known, a network of distance learning classes has been created in Lithuania (Fig 8).

Respondents were asked whether they would like to use the services of regional distance learning centres (Fig 9).

It is interesting to note that although 43 of those polled live in other cities, only 19 of them indicated that they would like to attend consultations and take examinations in their own regions. We think that answer could be explained by the students' desire to come to Vilnius for contact meetings (at VGTU), meet leading professors or lecturers, visit the library or settle some other affairs.

We have reached the part dealing with very important economic problems. The questionnaire asked the respondents to answer these questions: "Do you think that the tuition fee is reasonable? Who pays for your studies? Is it a financial burden for you?"

As can be seen in Fig 10, as many as $68 \%(86$ respondents) of those polled think that the tuition fee is too high whereas not a single one of them indicated that it is too low.
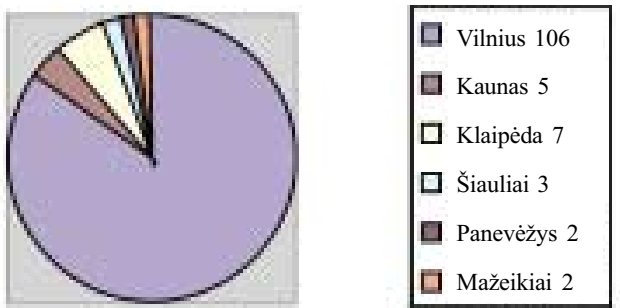

Fig 9. Distribution of respondents by the distance learning centre they wish to attend
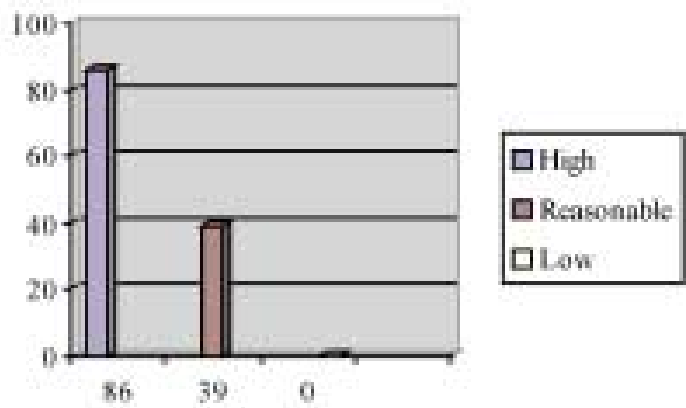

Fig 10. Respondents' opinion about the level of tuition fee

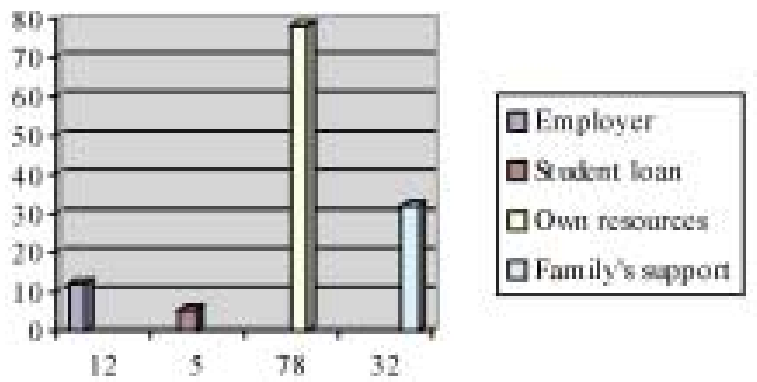

Fig 11. Distribution of respondents by financing

As can be seen in Fig 11, the overwhelming majority $62 \%$ (78 respondents) of those polled pay the tuition fee themselves, some of them get support from their families and 12 respondents indicated that it is their employers who pay their tuition fees. Interestingly, 5 persons have decided to take out the student loans.

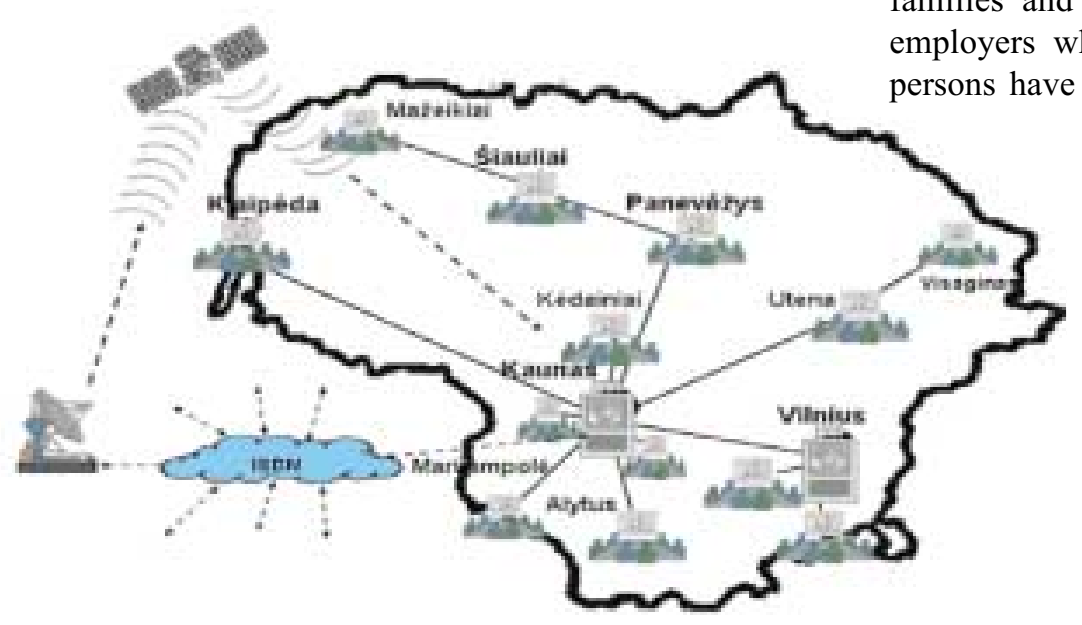

Fig 8. Network of regional distance learning centres in Lithuania [4] 

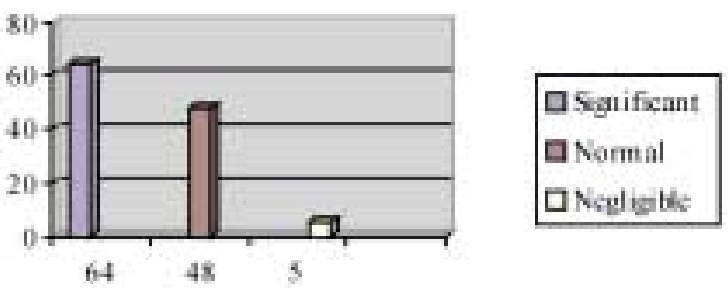

Fig 12. Respondents' opinion as to the cost of studies

As can be seen in Fig 12, the overwhelming majority of those polled $51 \%$ (64 respondents) think that the studies are a significant financial burden and only 5 people think that the cost of studies is negligible.

\subsection{Analysis of study materials}

Students' backgrounds are very diverse, so they have different experiences and expertise in different fields, also in numeracy and IT, and varying communication skills. It is not uncommon for complaints to come from those who do not understand the need for IT on their courses [9].

The third part of the above-mentioned questionnaire contained questions about the quality of study materials (Fig 13). It is worth noting that only second-year students and those who have already completed the programme of studies were asked to answer the questions of this part of the questionnaire. This group of respondents consisted of 98 persons $(78,4 \%)$. Those polled had to indicate the advantages and disadvantages of study materials and, in addition, they had to assess the quality on a rating scale.

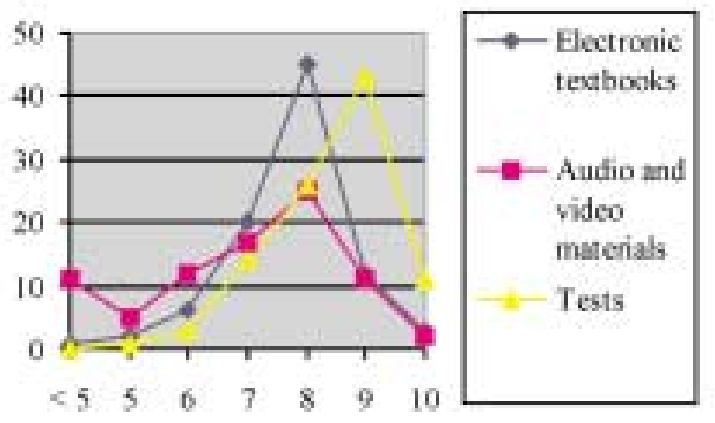

Fig 13. Respondents' opinions as to the quality of the study materials

A considerable part of those polled think that there is a lack of interactivity in electronic textbooks. Some other shortcomings have also been mentioned by the respondents, one of them being the lack of links and graphic information. On the whole, however, the level of electronic textbooks is considered quite high (average rating: 8 out of 10 ).

Most of the problems were found in the video and audio materials. As many as $40 \%$ of those polled think that this material is not comprehensive enough and video image are sometimes of poor quality.
The tests received the highest score. As many as 11 respondents gave them 10 points. With very few exceptions, they contained no faults.

\subsection{Social aspects of studies}

Part 4 of the questionnaire contains questions as to the reaction of the students' social environment to the fact that they have decided to study. Respondents were asked to score the reaction of their employer, family members, friends and acquaintances to their intention to renew their studies (Fig 14).

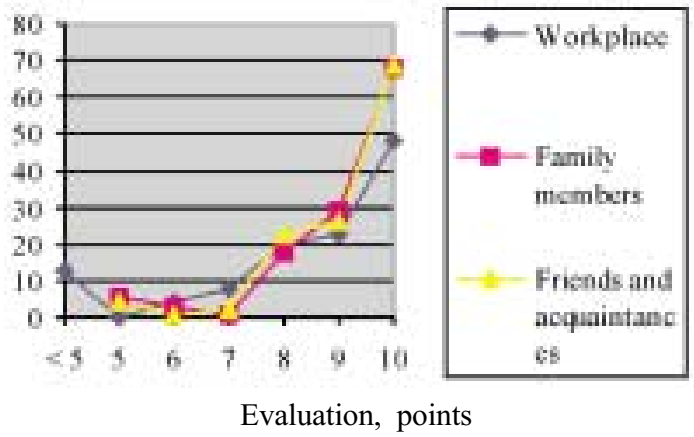

Fig 14. Respondents' opinion about the reaction in their social environment with respect to their studies

As can be seen in Fig 14, the problems most often occur at respondents' workplace: as many as 13 of those polled indicated that their employers' attitude towards their studies was negative. Only 6 participants of the survey participants encountered negative attitude in their families; all of them were women with small children. The overwhelming majority of respondents indicated, however, that they were supported in their endeavour to seek education, they gave it a score of 10 points.

When students were asked to share their comments and wishes, they said that the study materials should be better adjusted to the present situation and to the practices adopted in Lithuania. They also said they would like to get access to more up-to-date information and recommended that the amount of coursework be maintained at the present level.

\section{Conclusions}

1. Distance studies are very popular - over the period of 5 years the number of students has risen 6,7 times.

2 . The numbers of men and women enrolled in distant learning courses are roughly equal.

3. People under the age of 25 account for $41 \%$ of the student body; $25 \%$ of the students, however, are over the age of 36 .

4. Although most of the students (66\%) live in Vilnius, some live in areas that are far away from Vilnius.

5. The overwhelming majority $(95,2 \%)$ of those enrolled are employed. 
6. These are the main advantages of distance learning:

a) Convenient form of studies;

b) An opportunity to get acquainted with new information technologies;

c) Saving of time;

d) Fast communication;

e) Flexible choice of academic subjects;

f) Good professional training.

7. The main sources of information on distance studies are the press, the Internet, friends' recommendations, advertising materials and exhibitions.

8. The students are quite happy with the study materials. They gave the highest score to the tests. Electronic textbooks received the second highest score. Those polled indicated that they found some faults in video and sound materials.

9. Those who are in pursuit of education are accepted very positively in their social environment. Only some employers sometimes think that studies have some negative aspects. This could be due to competition, fear of the drain of employees, etc.

In summing up the research results, we can say that the distance studies at the Department of Construction Economics and Property Management of the Faculty of Civil Engineering are developing rapidly and are viewed positively by the students. It is necessary to achieve higher quality of study materials and improve organisation; this, however, cannot be done without investments. Additional funding could be obtained by entering new education markets in East European countries (Russia, Belarus) and in Western Europe as well as by undertaking international projects.

\section{References}

1. Kaufman, R.; Watkins, R.; Guerra, I. The future of distance learning: defining and sustaining useful results. Educational technology - the magazine for managers of change in education, Vol 41, No 3, p. 19-26.

2. Rumble, G. The costs and economics of open and distance learning. London: Kogan Page, 1997. 224 p.

3. Targamadzè, A.; Normantas, E.; Rutkauskienè, D.; Vidžiūnas, A. The new possibilities of distance learning (Naujos distancinio švietimo galimybès). Kaunas: Technologija, 1999. 246 p. (in Lithuanian).

4. Rutkauskienè, D.; Targamadzè, A.; Kovertaite, V. R. Distance learning (Nuotolinis mokymasis). Kaunas: Technologija, 2003. 255 p. (in Lithuanian).

5. Kee Low, B.; Sloan, B. A perspective on the digital interactive service industry for building professionals. Automation in Construction, Vol 10, Issue 2, January 2001, p. 229-237.

6. Web-site of distance learning of VGTU, Civil Engineering Faculty: http://www.vtu.lt/dmc01/sentv.htm

7. Kaklauskas, A.; Zavadskas, E. K.; Gikys, M.; Raslanas, S. Efficiency increase of distance learning by applying online intelligence computer learning systems. The second research workshop of EDEN: Research and policy in open and distance learning. Research workshop book. University of Hildesheim, Germany, 21-23 March 2002, p. 124-127.

8. Lagier, J. Distance learning and the minority student: special needs and opportunities. The internet and higher education, Vol 6, 2003, p. 179-184.

9. Williams, P. The learning Web. The development, implementation and evaluation of Internet-based undegraduate materials for the teching of key skills. Active learning in higher education, Vol 3 (1), 2002, p. 40-52.

\section{APPENDIX}

\section{QUESTIONNAIRE}

\section{Analysis of experience and efficiency of distance learning}

The following questionnaire should be filled in by the people who have started or have already been doing distance learning for Master's degree in the Department of Construction Economics and Property Management of Construction Faculty of VGTU. This questionnaire is aimed at the determination of the advantages and disadvantages of distance learning as well as wishes of students. The tutors and the lecturers are going to take these remarks into their consideration.

\section{Please, specify:}

Name, surname

Age

Your education

Name of place of work

Position (scope of work)

Home address (town is compulsory)

Contact information (telephone/fax, e-mail, mobile phone)

The specialisation of distance learning studies: 


\section{INFORMATION ON STUDIES}

1.1. Why have you chosen this particular form of studies? (Please, indicate all suitable variants)

$\square$ other people recommended $\quad \square$ convenient form of studies with no distraction from work $\quad \square$ good work opportunity in the future

$\square$ possibility to acquire a parallel $\square$ new method of studies occupation

$\square$ good professional training $\quad \square$ other (indicate)

1.2. In what respect, in your opinion, is distance learning better than other forms of studies? (Please, evaluate every study advantage in points form 1 to 10 )

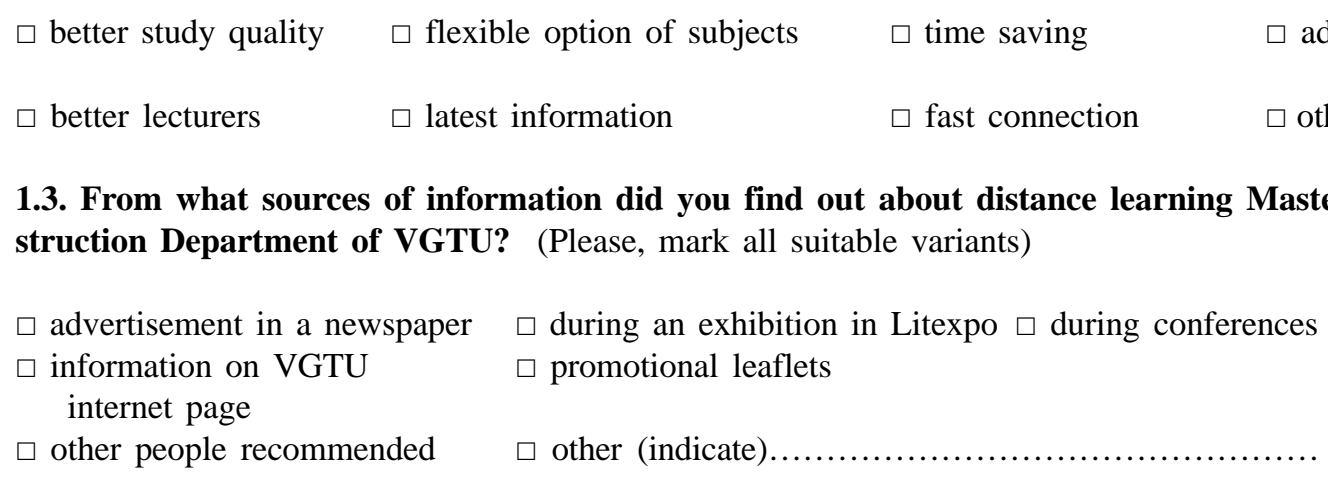

1.4. Evaluate the efficiency of information sources on distance learning Master studies in Construction Department of VGTU in points:
$\square 1$ point
$\square 3$ points
$\square 5$ points
$\square 7$ points
$\square 9$ points
$\square 2$ points
$\square 4$ points
$\square 6$ points
$\square 8$ points
$\square 10$ points

1.5. What are your study goals? (Please, mark all suitable variants)
$\square$ to improve knowledge
$\square$ to obtain a diploma of a new speciality
$\square$ to improve current working skills
$\square$ to acquire new knowledge
$\square$ opportunities to get a good job
$\square$ other (indicate).

1.6. What way of distance communication with lecturers is more acceptable and convenient for You? (Please, mark all suitable variants)
$\square$ e-mail
$\square$ intended contact meetings
$\square$ video conference
$\square$ telephone
$\square$ fax
$\square$ other (indicate).

1.7. What way of distance communication with tutors is more acceptable and convenient for You?
$\square$ e-mail
$\square$ fax
$\square$ video conference
$\square$ telephone
$\square$ intended contact meetings
$\square$ other (indicate).....

1.8. How would you evaluate the fact that the meetings with lecturers take place on Saturdays?
$\square$ very convenient
$\square$ I want to rest on Saturday
$\square$ convenient
$\square$ other (indicate).

1.9. Would like to use the services of regional centres of distance learning (to consult, to take exams)?
$\square$ yes
$\square$ no, at VGTU would be best 
1.9.1. If YES, specify where:
$\square$ in Kaunas
$\square$ in Panevėžys
$\square$ in Visaginas
$\square$ in Vilnius, VGTU
$\square$ in Klaipeda
$\square$ in Kèdainiai
$\square$ in Šiauliai
$\square$ in Mažeikiai
$\square$ in Utena

1.10. Are you satisfied with the study fee?
$\square$ high
$\square$ satisfactory
$\square$ low
$\square$ other (indicate)

\subsection{Who covers Your distance studies?}
$\square$ place of work
$\square$ family support
$\square$ study loan
other (indicate)
$\square$ own funds

1.12. Is the study fee a hard financial burden for You?
$\square$ very hard
$\square$ normal
$\square$ not substantial
$\square$ hard
$\square$ not noticeable
$\square$ other (indicate).

1.13. Should the duration of Your studies be changed while leaving the same price?
$\square$ to leave 4 semesters
$\square$ longer than 5 semesters
$\square$ to study 5 semesters
$\square$ other (indicate).

\section{ANALYSIS OF STUDY MATERIAL}

\subsection{How do you evaluate the quality of distance learning material?}

2.1.1. Electronic notes: (Please, mark all suitable variants)
$\square$ very high level
$\square$ high level
$\square$ insufficient amount
$\square$ insufficiently interactive
$\square$ insufficient graphic information, references

2.1.2. Evaluate the quality of electronic notes in points:
$\square 1$ point
$\square 3$ points
$\square 5$ points
$\square 7$ points
$\square 9$ points
$\square 2$ points
$\square 4$ points
$\square 6$ points
$\square 8$ points
$\square 10$ points

2.1.3. Video and audio material (Please, mark all suitable variants)
$\square$ very high level
$\square$ insufficient amount
$\square$ high level
$\square$ other (please, indicate).

2.1.4. Evaluate the quality of video and audio material in points:
$\square 1$ point
$\square 3$ points
$\square 5$ points
$\square 7$ points
$\square 9$ points
$\square 2$ points
$\square 4$ points
$\square 6$ points
$\square 8$ points
$\square 10$ points 


\subsubsection{Tests:}

$\square$ very high level

$\square$ insufficient amount

$\square$ high level

$\square$ other (please, indicate).

2.1.6. Evaluate the quality of tests in points:
$\square 1$ point
$\square 3$ points
$\square 5$ points
$\square 7$ points
$\square 9$ points
$\square 2$ points
$\square 4$ points
$\square 6$ points
$\square 8$ points
$\square 10$ points

2.2. Do you use internet electronic training systems created by SENTV Department?
$\square$ yes
$\square$ no
$\square$ partially
$\square$ other (please, indicate)

2.3. Evaluate the quality of use internet electronic training systems created by SENTV Department in points:
$\square$ point
$\square 3$ points
$\square 5$ points
$\square 7$ points
$\square 9$ points
$\square 2$ points
$\square 4$ points
$\square 6$ points
$\square 8$ points
$\square 10$ points

\section{NEEDS AND REQUESTS}

3.1. What is the reaction of your environment to Your studies?

a) place of work

Please, explain and evaluate in points from 1 to 10.

b) family and close relatives

Please, explain and evaluate in points from 1 to 10.

c) friends and acquaintances

Please, explain and evaluate in points from 1 to 10.

d) other

Please, explain and evaluate in points from 1 to 10.

3.2. What additional services would be necessary for you? Please, list:

3.3. Would you like more contact meetings?

$\square$ Yes $\quad \square$ No

3.4. Would you like to change anything?

$\square$ I would not like $\quad \square$ I would like

Please, explain:

3.5. Your other requests and proposals.

\section{THANK YOU FOR YOUR ANSWERS!}

The data of this questionnaire is going to be used only for the purposes of research and, with regard to the answers of respondents, to be used for the improvement of study conditions. 